\title{
MEMOIRS
}

\section{WALTER ERNEST HINDMARSH HICKOX}

'WALly' Hickox, as he was known to his friends, was born in October 1903 and died in October 1969, after a short illness.

After matriculating, he decided to become an actuary and in 1920, at the age of 16, he entered the service of the Prudential Assurance Company.

In December of that year he passed the whole of Part I of the examinations and, apart from a blank year in 1921, he rapidly passed through the examinations and by May 1925 had become a Fellow.

In those days the promotion of young actuaries to posts of responsibility was slower than obtains today, but his progress in the Company was steady and impressive. By 1934 he was a Principal, then at six-year intervals he progressed through the ranks of junior and senior officer, becoming an Assistant Actuary to the Company in 1950.

During his career he took an active part in the affairs of the Institute and of the Students' Society, of which he was Honorary Secretary from 1933 to 1935 . In 1936 he submitted a paper entitled 'Surrender Values and Paid-up Policy Amounts' (J.I.A. 80, 32).

From 1937 to 1950 he was an examiner, acting as Secretary to the Board of Examiners from 1945 to 1947 when he became Chairman of the Board, a position he held for three years. He was a Member of Council for ten years and was Joint Editor of the Journal from 1955 to 1957.

Hickox was a man of outstanding academic ability in his profession with an enquiring mind which could penetrate deep into the roots of any problem. However, it would be true to say that his mind ranged so widely on every aspect of a problem that he was at times reluctant to draw the conclusions or to make the decisions which would have justified his labours.

It would be wrong to give the impression that Hickox had no time for activities outside the actuarial world. He was a keen sportsman, playing football with great gusto and achieving a high standard of tennis. As would be expected, he was a distinguished chess player and won many trophies for his successes at the game.

He will be long remembered with affection by his many friends and colleagues in the profession.

A. S. Clarke

\section{ALFRED TREVOR HAYNES}

Alfred Trevor Haynes died suddenly on 14 November 1969 at the age of 62 . He was born at Blundellsands and, after education at Haileybury, entered the Royal Insurance Co. Ltd. Head Office in Liverpool as an actuarial student in 1924. He completed the examinations of the Institute in 1927 when he was only 20 years of age and then moved to the Caledonian in Edinburgh, where he obtained his Fellowship of the Faculty in 1930. In 1935, when R. J. Kirton, who was then Assistant Secretary at the London Office of the Scottish Amicable, moved to the Head Office in Glasgow, Haynes was appointed to succeed him in London. There then began a lifelong personal friendship, professional collaboration and a remarkable similarity of careers. It seemed natural that three years later, when Kirton went back to London to become Chief Officer of the Equity \& Law, Haynes should follow him in Glasgow as Joint Actuary of the Scottish Amicable. In 1940 Haynes also joined the Equity \& Law as Actuary and Secretary, and 
he and Kirton together guided that office through the difficult years of the war. In 1947 Haynes returned to the Scottish Amicable to become, in the following year, General Manager and Actuary, a position which he held until his untimely death.

His most notable contributions to actuarial literature were the two papers which he and Kirton together submitted on widely diverse subjects. The first-on income tax in relation to social security - was submitted to the Institute on 14 May 1943 and had a major influence on the solution of problems arising from the introduction of P.A.Y.E. The simplification of the personal income tax system and its co-ordination with the social security system was further developed in evidence submitted by the authors to the Royal Commission on the taxation of profits and income in May 1951. The second joint contribution was presented to the Faculty in March 1952 entitled 'The Financial Structure of a Life Office' and postulated that the maintenance of interest yield for the right future term and of capital security at the right future date was of much greater fundamental importance than the maintenance of present capital security. It emphasized that the structure of a life office should always be regarded as involving inter-related assets and liabilities. This classic paper is still recommended reading for students.

Apart from these major joint papers, Haynes was a frequent contributor to discussions at Sessional Meetings of both the Institute and the Faculty although his visits to London in later years, by force of circumstances, became less frequent. His contributions to discussions showed the very wide range of his interests, but were particularly cogent in relation to statistical and investment matters.

He was a tutor in the immediate pre-war period and played a leading part in the revision of the examination syllabus after the war and the co-ordination of the production of textbooks for the new syllabus. He served on the Council of the Institute for ten years between 1945 and 1955 and was a Vice-President from 1950 to 1953 . Having served as Honorary Secretary of the Faculty of Actuaries from 1952 to 1955, he became President of the Faculty in 1962 and his term of office culminated in the Seventeenth International Congress held in Edinburgh and London in 1964. He was awarded the C.B.E. in the Birthday Honours that year and was elected a member of the Deutsche Gesellschaft für Versicherungsmathematik. He was Chairman of the Associated Scottish Life Offices in 1954-6 and at the time of his death was by several years the senior member of that body. He was Chairman of the Scottish Actuaries' Club in 1958/9.

Trevor Haynes's abiding interest was the application of the actuarial principles which he enunciated to the operation of a life office. He was the kindliest and most thoughtful of colleagues, attaching great importance to the proper training and encouragement of students. He set himself the highest standards of conduct, both personal and professional, and if one was tempted to bend one's principles even a little on the grounds of expediency one was brought back to the proper path with such gentleness but firmness that one was left with even greater affection and admiration. An extremely hard and dedicated worker himself, he was an inspiration to his colleagues and subordinates and a true leader of men.

Outside his professional work he was active on committees of the National Trust for Scotland and the British Sailors' Society. As those who have been privileged to visit him at his home will know, he had a great love of people and was essentially a family man. He is survived by his wife and three married daughters.

T. S. JENKINS 